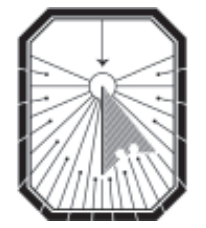

KYIV-MOHYLA

HuMANitiES JOURNAL

KYIV-MOHYLA SCHOLARLY PEER-REVIEWED JOURNALS

\title{
Lesia Ukrainka and Qiu Jin: The Confluence of Their Poetic Worlds via Translation
}

Author(s): Nataliia Isaieva, Olha Vorobei

Source: Kyiv-Mohyla Humanities Journal 8 (2021): 121-145

Published by: National University of Kyiv-Mohyla Academy

http://kmhj.ukma.edu.ua/ 


\title{
Lesia Ukrainka and Qiu Jin: The Confluence of Their Poetic Worlds via Translation
}

\author{
Nataliia Isaieva \\ Taras Shevchenko National University of Kyiv, \\ Institute of Philology, \\ Far Eastern and Southeastern Languages and Literatures Department
}

\section{Olha Vorobei}

Taras Shevchenko National University of Kyiv, Institute of Philology,

Far Eastern and Southeastern Languages and Literatures Department

\begin{abstract}
This article deals with the poetry of two prominent writers: Ukrainian poetess Lesia Ukrainka (1871-1913) and Chinese poetess Qiu Jin (1875-1907). The diversity of wide fields of selfexpression of both poetesses created the grounds for a broad and comprehensive comparison in terms of poetic, thematic, and literary similarities. The article provides a background to the translations of Lesia Ukrainka in China and accounts for the perception of Lesia Ukrainka's poetry in China in the light of the poetic world of Qiu Jin. The main aspects of the poetic discourses of Lesia Ukrainka and Qiu Jin are outlined and studied within the core concept of the national heroine in China, formed by Qiu Jin, consisting of key elements important for the perception of Lesia Ukrainka's works - revolution, nationalism, and feminism.
\end{abstract}

Key Words: Modernity, feminism, nationalism, revolution, Lesia Ukrainka, Qiu Jin, Chinese modern literature.

\section{(2)}

\section{In Search of Translation: Lesia Ukrainka's Works in China}

The issue of the reception of the translation of Lesia Ukrainka's poetry and the perception of the poetess's artistic image in China is a component of the general process of Ukrainian-Chinese literary communication. Pavel Toper made an essential remark noting that in the 21st century translation should be understood as a "special 'layer' of fiction works, which holds a very definite place in the system of literary relations, with its characteristics, typological properties, rules of functioning, etc., associated with their 'double' affiliation and the emergence 'on the border' of two different cultures..." Therefore, the study of translation as the "main channel of interlingual literary 
interaction"2 involves the analysis of a set of literary factors (external and internal) that determine the emergence of new aesthetic values in a foreign cultural environment.

Lesia Ukrainka's poetry in Chinese was published for the first time in the early 1920s, when Chinese society was undergoing a dramatic modernization of all spheres of life. In this article the word modernization is used within the concept of modernity (not modernism) in its broadest sense as a phenomenon that "contributes to the objective expression of the spirit of time actuality." 3 The characteristic features of modernity were clearly defined by the American researcher Art Berman:

Modernity includes certain intellectual movements, political directions, and socioeconomic trends and involves the setting of optimistic social goals. ... A new form of human selfconsciousness is to intervene in history, not only as a mode of awareness, but as a mode of power... ${ }^{4}$

Political events that determined the values, needs, and goals of Chinese society at the beginning of the 2oth century were, on the one part, the Xinhai Revolution (19111913), which led to the overthrow of the Manchu Qing dynasty, and, on the other part, the May Fourth Movement (1919) for national liberation, which started "a new era of modernization of the country in various aspects, but primarily in cultural, educational, ideological, and political spheres."5 Both political events sharpened the feelings of patriotism and national dignity of the Chinese, forced the conscious intelligentsia to think about ways of uniting the nation and finding the foundations of an up to date (modern) cultural orientation for the Chinese nation. This was one of the program tasks of the New Culture Movement, ${ }^{6}$ activists of which were representatives of the intellectual elite who were educated in Japan, America, and Europe, and therefore considered Western ideas in the fields of philosophy, politics, and literature to be the main sources for Chinese cultural modernization. This coincided with the intensification of literary translation, which not only expanded Chinese cultural discourse but also stimulated the diversity of Chinese writers' fiction practices. At the beginning of the 1920 s two

2 Toper, Perevod v sisteme sravnitelnogo literaturovediniia, 16.

3 Jurgen Habermas, "Modern - nezavershennyi proekt [Modernity - An Incomplete Project]," Voprosy Filosofii 4 (1992): 41.

$4 \quad$ Art Berman, Preface to Modernism (Urbana: University of Illinois Press, 1994), 3.

$5 \quad$ Oleksii Koval, "Yak rukh 4 travnia zminyv Kytai [How the May Fourth Movement Has Changed China]," Ukraine-China, 2019, accessed October 18, 2021, https://sinologist. com.ua/koval-o-yak-ruh-4-travnya-zminyv-kytaj/.

6 The New Culture Movement was a social and educational movement in China in the 1910s and 1920s. Its activists Lu Xin, Li Dazhao, Chen Duxiu, Liu Bainong, Hu Shi, and others criticized classical Chinese ideas and promoted a new Chinese culture based upon Western ideals like democracy and science. The movement promoted the democratization of literature, the usage of the Chinese colloquial language baihua instead of archaic wenyan, the end of the patriarchal family in favor of individual freedom and women's liberation, etc. 
opposite tendencies emerged in Chinese fiction discourse. The first was focused on strengthening the subjective principle in literature with an emphasis on individual characteristics, emotions, and perception of the lyrical hero. ${ }^{7}$ It was inherent, especially, in the artistic imagination of the representatives of Chuàngzàoshè (The Creation Society), who were involved in the translation of the works of European Romantic poets such as Byron, Heine, Goethe, Keats, Shelley, Schiller and others, and were thus inspired by these authors. ${ }^{8}$ The main criterion for choosing texts for translation had always been artistic merit. Unfortunately, Lesia Ukrainka's ${ }^{9}$ poetic texts, which were spiritually and aesthetically close to European Romanticism, were not examined by Chinese artists in their discourse. Instead, the ideological orientation of the works of the Ukrainian poetess attracted the attention of supporters of a second direction - a utilitarian one. These were the members of Wénxué yánjiūhui (Society for Literary Studies), headed by famous writer, literary critic, and public figure Mao Dun (Shen Yanbin, 1896-1981). Members of this literary society believed that literature should reflect human life, and the object of its images should be the "blood and tears"10 of the humiliated and offended. It is from this point of view that Mao Dun interpreted the poetic works of Lesia Ukrainka.

In 1921, in a thematic issue of Xiăoshuō yuèbào (Short Story Monthly), devoted to the literature of enslaved peoples, Mao Dun published his own translation of Lesia Ukrainka's dramatic poem "Vavilonskyi polon" (The Babylon Captivity). ${ }^{1}$ The criterion for choosing this drama for translation was the socio-historical concept, which Mao Dun mentioned in the foreword: "The literature of each nation reflects its national character, a fusion of historical, social background, and the leading ideas of the time!"12

Vladislav Sorokin, "Literatura novogo Kitaia [Literature of the New China]," in Dukhovnaya Kultura Kitaia, vol. 3, "Literatura. Yazyk i Pismennost"

(Moscow: Vostochnaia literatura, 2008), 155.

See more about the role of translation in the modernization of Chinese poetic discourse of the 1920 and 1930 in Kateryna Murashevych, "Khudozhno-estetychnyii fenomen poezii ' 4 Travnia' v kytaiskii literaturi pochatku 20 stolittia [The ArtisticAesthetic Phenomen of May Fourth Poetry in Chinese Literature at the Beginning of 2oth Century]" (Ph.D. diss, Taras Shevchenko National University of Kyiv, 2011), 24-35. Lesia Ukrainka attached great importance to translation as a way for the modernization of culture, trying to "open its too narrow frameworks." She reveled in the translation of Heine's poetry, as well as the poetry of Byron, Hugo, Mickiewicz, thus trying "to open the framework" of her own creative works. See Solomiia Pavlychko, Dyskurs modernizmu v ukrayinskii literaturi [The Discourse of Modernism in Ukrainian Literature], 2nd ed. (Kyiv: Lybid, 1999), 44.

$10 \quad$ Murashevych, "Khudozhno-estetychnyii fenomen," 48.

11 In the same issue Mao Dun published the translation of Ukrainian wedding songs, and $\mathrm{Lu}$ Xun published the translation of the chapter "A Brief Review of Ukrainian Literature" from Gustav Karpeles, The History of World Literature (Allgemeine Geschichte der Weltliteratur). See more in Ge Baoquan, "Ukrainska literatura v Kytai [Ukrainian Literature in China]," trans. Ivan Chyrko, Vsesvit 8 (1987): 139-40; Zhu Hong and He Rongchang, "Lesia Ukrainka v Kytai [Lesia Ukrainka in China]," Vsesvit 3 (1994): 162-63. Ge Baoquan, "Ukrainska literatura v Kytai," 139. 
It is quite remarkable that the primary source for Mao Dun was the Englishlanguage edition Five Russian Plays: With One From Ukrainian (1916). ${ }^{13}$ The compiler and translator of this edition, Carl Eric Bechhofer Roberts, in his foreword described Lesia Ukrainka as a European author who overcame a narrow "ultra-national" framework of writing, underlining: "The Babylonian Captivity ... represents the enslavement of the Ukraine by its powerful neighbors; but its style is a victory."14

This idea probably influenced the interpretation of the poem translated by Mao Dun. In this issue Lesia Ukrainka's work represents Ukrainian literature as a component of the European artistic space of those peoples who fought for their self-determination Poles, Czechs and Slovaks, Finns, and others. Mao Dun adds general comments that the Ukrainian people "always fought back against the invaders" and "passed their song heritage, also a kind of historical chronicle," from generation to generation. ${ }^{15}$ The translator did not comment on the text of the poem, but in this context noted that the image of Lesia Ukrainka combined the features of a European intellectual and at the same time - a profoundly national poetess who cares about patriotism, national resistance, and human dignity.

Further interpretation of Lesia Ukrainka's works in China (especially since the late 1940s) was provided within the scope of the official discourse of Sino-Ukrainian (or rather Sino-Soviet) literary relations, "which have reached the most intensive development and covered all known types of interaction." ${ }^{16}$ Among other things, the solemn cultural events of this interaction include the celebration of literary anniversaries and the awarding of literary prizes. Oksana Zabuzhko notes that such "solemn events" formed, in particular, "party resolutions, and a canon of the general perception and interpretation of the awarded figure." ${ }^{17}$

In 1948, on the 35th anniversary of Lesia Ukrainka's death, five of her poems were translated by Ge Baoquan ${ }^{18}$ and published in the July issue of Sūlián wényi (Soviet Literature and Art). These were: "Mii Shliakh" (My Path), "Nadiia” (Hope), "Skriz plach, i stohin, i rydannia" (Vain Tears), "Vechirnia hodyna” (Evening Hour), "Hrai, moia pisne" (Sing, O My Song). An article of Soviet critic Genrikh Eichler, "On Lesia

13 Five Russian Plays, With One from the Ukrainian, trans. and introduction Carl Eric Bechhofer, Internet Archive, 2020, accessed October 18, 2021, https://archive.org/ details/fiverussianplaysoorobe.

14 Five Russian Plays, With One from the Ukrainian, 16.

15 Ge Baoquan, "Ukrainska literatura v Kytai," 139.

16 Oleh Mykytenko, "Ukrainsko-kytaiski literaturni zviazky v yikh istorychnomu rozvytku [Sino-Ukrainian Relations Within the Scope of Their Historical Development]," in Ukraine-China: Ways of Cooperation (Kyiv: MPP “INTEL," 1993), 110. Oksana Zabuzhko, Notre Dame D’Ukraine: Ukrainka v konflikti mifolohii [Notre Dame d'Ukraine: Ukrainka in a Conflict of Mythologies] (Kyiv: Fakt, 2007), 63.

18 Ge Baoquan (1913-200o) was a well-known Chinese literary critic, translator, and sociopolitical figure. He translated the poetry of Taras Shevchenko, Ivan Franko, Lesia Ukrainka, as well as conducted research on the life and works of these artists. In 1989, Ge Baoquan won the Ivan Franko Prize for the promotion of Ukrainian literature in China. 
Ukrainka," was also published in this issue. ${ }^{19}$ In it the author presented a canonical version of the poetess-fighter, revolutionary, and follower of Taras Shevchenko's ideas, and also referred to Ivan Franko's emblematic statement about Lesia Ukrainka "as the only man in Ukraine." ${ }^{20}$ Such a conception was designed to meet the ideological requirements of Chinese literary criticism, adhered to by researchers almost until the end of the 2oth century. Ideological clichés, often used in these articles, described Lesia Ukrainka as "a writer of the revolutionary-democratic trend"; "the main theme of her poetry is resistance to despotism and the struggle for national liberation" ${ }^{21}$; "her poems are full of revolutionary-democratic ideas and love for the Ukrainian land and people"22; "in her works [she] highly praised the courage and fervor of the fighters for a better future for all of mankind"23; Lesia Ukrainka "inherited the glorious traditions [of Taras Shevchenko] and continued his holy cause of struggle for the liberation of his people," ${ }^{24}$ etc.

However, translation practice in China was not so radical and unambiguous, ${ }^{25}$ which allows us to talk not only about the ideological, but also about the aesthetic factor in the choice of texts for translation. The well-known Ukrainian orientalist Olena Ohnieva drew attention to this in her article "Kanon fengliu i osobystyi shliakh Lesi Ukrainky" (The Fengliu Canon and Lesia Ukrainka's Personal Path), ${ }^{26}$ where she analyzed the above-mentioned translations of Ge Baoquan in terms of the reception of Lesia Ukrainka's works in the Chinese poetic tradition. It is noteworthy that the researcher paid considerable attention to the personality of the translator, on whom, in her opinion, the psychological and ethnic compatibility of the work with targetdomain literature depends. In the hieroglyphic "visualization" of the images of the poem "Vechirnia hodyna," Ohnieva traces the aesthetics of the Yin-Yang contrast,

19 Ge Baoquan, "Wukelan wenxue zai Zhongguo [Ukrainian Literature in China]," Zhongguo Fanyi 3 (1988): 37.

20 According to Zabuzhko's accurate observation that "in Soviet literature the canonized Ukrainian classics had to be revolutionary democrats, materialists and atheists..." See in Zabuzhko, Notre Dame D'Ukraine, 97.

$21 \quad$ Mai Xinhe, "Wukelanyingka shi sishou [Four Poems by Lesia Ukrainka]," Shijie Wenxue 7-8 (1962): 138.

22 Zhu Bianzhe, "Wukelan Shixuan [Selected Ukrainian Poems]," Sulian Wenxue 2 (1987): 68.

23 Zhu Hong, He Rongchang, "Lesia Ukrainka v Kytai," 162.

24 Zhou Zhonghe, "Ukrainska literatura blyzka ta doroha kytaiskomu narodu [Ukrainian Literature is Close and Dear to the Chinese Nation]," in Ukraine-China: Ways of Cooperation (Kyiv: MPP “INTEL," 1993), 132.

25 This can be proved by the moderate choice of poetry for translation. Such paradigmatic poems as "Predawn Lights" (Dosvitni vohni) and "Contpa spem spero!" were not translated. Instead, Chinese translators preferred Lesia Ukrainka's early lyrics. The philosophical and lyrical poem "My Path" has the most interpretations (4 in total). 
which is quite inherent in traditional Chinese poetry, and finds figurative and emotional associations with the works of Chinese classics (e.g., Li Bo, Xie Lingyun, Ou Yangxiu) and poets of the first half of the 2oth century (Dai Wangshu, Qiu Jin, Bing Xin, etc.). Overall, Ohnieva's concept is interesting and promising, although it requires a wider range of typological comparisons for deeper textual analysis. Additionally, the researcher does not pay enough attention to the important problem of the mediation of Russian translation for the translation of Ukrainian literary works. Ohnieva claims that in the line of the poem "Vechirnia hodyna" "orchards and white huts are all about," ${ }^{27} \mathrm{Ge}$ Baoquan deliberately introduced the image of snow: "gardens are all around, and huts more beautiful than snow"28 in order to complement the image of the night according to Chinese poetic tradition. ${ }^{29}$ However, this image was added by Russian translator Vera Zviagintseva.

It is worth emphasizing that the poetry of Lesia Ukrainka was translated into Chinese exclusively from Russian translations throughout the 2oth century. ${ }^{30}$ It is obvious that Chinese translations were significantly influenced by the interpretations of Russian translators, who sometimes changed the text of the original quite freely. In 1962 four poems of Lesia Ukrainka translated by Mai Xinhe were published in the journal Shijiè wénxué (World Literature): "Slozy-perly" (Pearl Tears), "Slovo, chomu ty ne tverdaia krytsia” (Word, Why Aren't You Cold Steel...), “Son” (The Dream”, and "Khto vam skazav, shcho ya slabka” (Who Told You That I'm Weak). In the afterword, the Chinese translator noted that in the Russian translation of the poem "Khto vam skazav, shcho ya slabka," poet Samuil Marshak added the last line "to make the idea of the poem sound more complete." ${ }^{11}$ In this way, the last stanza took the following form:

And meanwhile I shall stay alive,

like sea-waves in the doldrums,

that seem to sleep and will not revive,

But the sea is longing for the surf. $3^{2}$

27 Lesia Ukrainka, Zibrannia tvoriv [Collected Works], vol. 1 (Kyiv: Naukova dumka, 1975), 83. ("Krugom sadochki, bilenki chaty," translated by Olha Vorobei.)

28 Ge Baoquan, "Wukelanyingka Shi Wuzhang [Five Poems by Lesia Ukrainka]," Sulian Wenyi 33 (1948): 108. ("Zhōuwéi shì huāyuán, máoshè - bǐ xuě piàoliang," translated by Olha Vorobei.)

29 Ohnieva, "Kanon fengliu," 78.

30 In 2017, for the first time, selected prose works by Lesia Ukrainka were translated from Ukrainian originals and published in Andrii Pecharskii and Kewen Sun, Antolohiia ukrainskoho ta kytaiskoho pysmenstva. Perekladatski innovatsii u Lvivskii "Alma Mater" [An Anthology of Chinese and Ukrainian Belles-Letters. Translation Innovation at the Lviv "Alma Mater"] (Lviv: Ivan Franko National University of Lviv, 2017), 172-235.

$31 \quad$ Mai Xinhe, "Wukelanyingka shi sishou," 139.

32 Lesia Ukrainka, "Kto vam skazal chto ya chrupka... [Who Told You I Am Weak...]," trans. Samuil Marshak, Wikilivres.ru, 2020, accessed October 18, 2021. ("Chto zh, budu zhit ya, kak zhivot / Volna v chasy pokoia - / Kak budto spit poverkhnost vod, / No more zhdet priboia," translated by Olha Vorobei.) 
Given that Lesia Ukrainka crossed out this entire unfinished stanza in the manuscript of the poem, it becomes obvious that the translator distorted the author's idea. Marshak reconciled the image of the lyrical heroine with the official concept of a strong woman-fighter, always ready to resist, and Mai Xinhe consciously reproduced the concept in his translation.

In the 1980 s the ideological climate in China began to change - society was going through the traumatic experience gained during the Cultural Revolution (1966-1976). Literature reacted symptomatically to these events, and the main problem for poetry, first of all, was the rethinking of history and human existence from humanistic positions, the recognition of the value of the human personality, and the complexity of its inner world. In this regard, Lesia Ukrainka's early lyrics translated by Lan Man were published in 1987 in a specialized issue of Soviet Literature and Art (Sūlián wényi), devoted to Ukrainian literature: "Naprovesni" (In Early Spring), "Konvaliia” (Lily of the Valley), "Shliu do tebe malyi sei lystochok" (Sending You This Small Leaf), "Mii schliakh, rozbyta charka" (My Path is a Broken Glass), "Yak dytynoiu buvalo" (What it Was Like as a Child). The sad mood and allegorical imagery of these poems evokes associations with Chinese Misty poetry. ${ }^{33}$ Significantly, feminine discourse appears in these translated poems. Lesia Ukrainka's lyrical heroine feels the girlish confusion of her existence and the "romantic confrontation of fate" 34 in choosing her life path, and finally - love experiences veiled by allegorical images.

The short "lyrical digression" in the reception of the poetic world of the Ukrainian poetess was replaced in the 1990 os by Lan Man's revolutionary-feminist reading of her poetry. The 1995 Fourth World Conference on Women in Beijing marked a significant turning point for the global agenda on gender equality. The event revealed extensive contacts between Chinese scholars and feminists around the world, as well as stimulating the development of gender-sensitive literature in China. ${ }^{35}$ An anthology, Měiōu nüzǐ shīxuăn (Selected Women's Poetry of Europe and America), containing iconic (according to Chinese compilers) works of prominent poetesses from ancient Greece to the 2oth century, was published in conjunction with the conference. The anthology included two poems of Lesia Ukrainka translated by Li Hai: the poetic manifesto "Mii shhliakh" (My Path), and the revolutionary march "Choho marselsku

Misty poetry (ménglóngshī) - a modernist trend in Chinese poetry of the 1970s-198os. It is characterized by "a critical understanding of reality, high ideals, the spirit of resistance, deep reflection on history, society and human existence, the search for harmony of life." See Marina Khaidapova, "Ideino-khudozhestvennoe svoeobrazie kitaiskoi tumannoi poezii [The Conceptual and Artistic Peculiarity of Chinese 'Misty Poetry']," Vestnik Buratskogo gosudarstvennogo universiteta 8 (2012): 109. This semantic component was allocated by Halyna Levchenko in the poem "Mii schliakh" and denominated as a "poetic manifesto." See Halyna Levchenko, "Semiosfera liryky Lesi Ukrainky [The Semiosphere of Lesia Ukrainka's Lyrics]" (Doctor of Philology diss., Ivan Franko State University of Zhytomyr, 2015), 106. Women's Prose: A Revision of the Canon], 2nd ed. (Kyiv: Logos, 2018), 189-207. 
pisniu chuty"? (Why is the Marseille Song Heard?) from the Pisni pro voliu (Songs of Freedom) cycle. The lyrical heroine of these works is a determined, strong, freedomloving woman who would meet the feminist ideals of any national environment. She has the characteristics of the woman warrior, who in Western culture is associated with the phenomenon of Joan of Arc. ${ }^{36}$

In 2oth century Chinese culture such a phenomenon was represented by legendary poetess-revolutionary Qiu Jin (1875-1907). Thus, consciously, or involuntarily, Chinese literary critics chose those poems by Lesia Ukrainka that evoked in the imagination of their compatriots the image of their own national heroine. This thought is supported by Chinese Ukrainian scholars Zhu Hong and He Rongchangin in their article "Lesia Ukrainka v Kytai" (Lesia Ukrainka in China). ${ }^{37}$ They consider that comparative studies of the works of Lesia Ukrainka and Qiu Jin are appropriate, as both poetesses, according to the researchers, are united by "a sense of protest, a thirst for achievement, and the spirit of revolutionary struggle," ${ }^{8}$ as well as a call for the liberation of women. Although the rhetoric of biased Soviet literary criticism is heard in this thesis, a deeper meaning behind these ideological clichés can be found. The figure of Qiu Jin in China is shrouded in legends that reflect the national concept of female heroism and sacrifice (martyrdom). ${ }^{39}$ It is worth assuming that this very concept prepared the ideological and fictive discourse for the perception of Lesia Ukrainka's artistic image in China.

\section{Lesia Ukrainka and Qiu Jin: The Typology of Poetic Thinking From a Translation Perspective}

Literary translation is usually motivated by the willingness of a national culture to accept and/or borrow certain foreign material. Aleksandr Veselovskii's thought that "the process of borrowing does not assume empty space in the target literature, but, on the contrary, it needs countercurrents, a similar direction of thinking, and analogous

36 Notably, Ukrainian poet Maksym Rylskyi called Lesia Ukrainka the "Joan of Arc of our literature." As well, Yevhen Malaniuk compared Lesia Ukrainka with Joan of Arc: "Yes, the character and will of this weak woman were and remain exceptional, so to speak, throughout all of Europe. There was something of the French Joan of Arc in her..." See Yevhen Malaniuk, "Do rokovyn Lesi Ukrainky (13.II.1871) [On Lesia Ukrainka's Anniversary (February 13, 1871)]," in Knyha sposterezhen. Statti pro literaturu (Kyiv: Dnipro, 1997), 202.

37 Zhu Hong and He Rongchang, "Lesia Ukrainka v Kytai," 162-63.

38 Zhu Hong and He Rongchang, "Lesia Ukrainka v Kytai," 162-63.

39 See Ying Hu, "Gender and Modern Martyrology: Qiu Jin as Lienü, Lieshi, Oo Nülieshi," in Beyond Exemplar Tales: Women's Biography in Chinese History (Berkeley; Los Angeles; London: University of California Press, 2011), 121-36; Xian Wang, "Flesh and Stone: Competing Narratives of Female Martyrdom from Late Imperial to Contemporary China" (Ph.D. diss., Department of East Asian Languages and Literatures of the University of Oregon, 2018), 100-28. 
images of fantasy," is well-known..$^{40}$ The poetic world of Qiu Jin became such a direction of thought and figurative imagination for the perception of Lesia Ukrainka's poetry in China. Lesia Ukrainka and Qiu Jin were contemporaries, living during the past fin de siècle. Lesia Ukrainka was born in 1871 and died in 1913 after a "30-year battle with tuberculosis"41; Qiu Jin was born in 1875 and was executed by Qing authorities in 1907 after an assassination attempt on Governor En Ming on the eve of theXinghe Revolution (1911-1913). Both women lived short lives, full of dramatic collisions and tragic events that took place against the cultural and historical background of the turn of the 19th and 2oth centuries. Vira Aheieva notes:

Boundaries of cultural epochs are always marked by a comprehensive crisis of fundamental values, disappointment in former authorities, and a search for new ideas and guidelines... The usual conceptions of good and evil, beauty and ugliness, center and margin are destroyed...42

This characteristic defines the peculiarities of the spiritual climate of that time in Ukraine and China and the extraordinary nature of both Lesia Ukrainka and Qiu Jin.

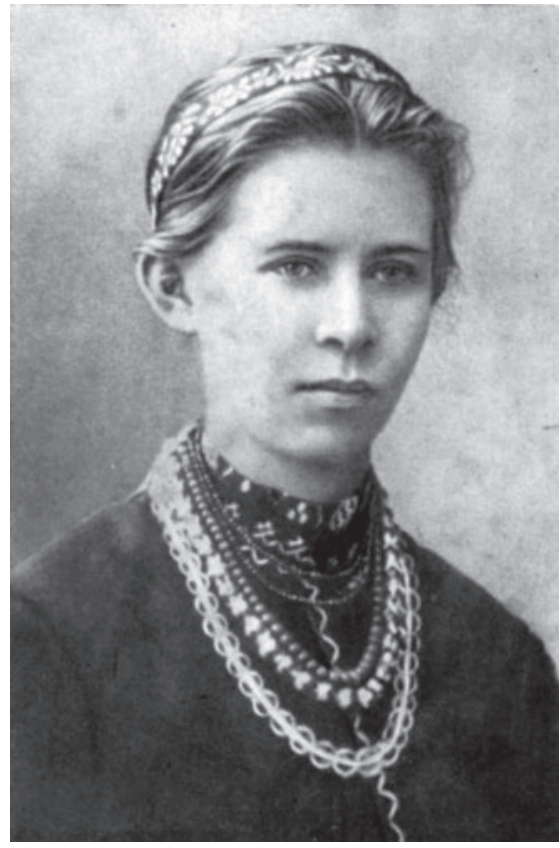

Figure 1. Lesia Ukrainka (1871-1913)

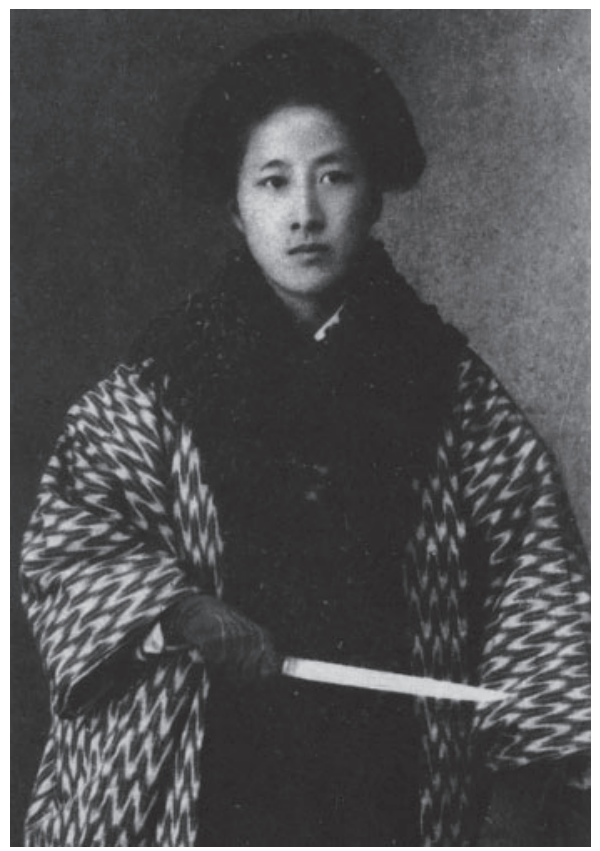

Figure 2. Qiu Jin (1875-1907)

40 Aleksandr Veselovskii, Razyskaniia v oblasti russkogo dukhovnogo stiha [Research in the Field of Russian Clerical Poetry] (Saint Petersburg: Imperatorskaia Akademiia Nauk, 1889), 115.

41 This is how Lesia Ukrainka described her state of health in a letter to her sister Olha Kosach-Kryvyniuk, dated August 8, 1912. See Lesia Ukrainka, Zibrannia tvoriv [Collected Works], vol. 12 (Kyiv: Naukova dumka, 1979), 406.

42 Vira Aheieva, Zhinochyi prostir: Feministychnyi dyskurs ukrainskoho modernizmu [Female Space: The Feminist Discourse of Ukrainian Modernism] (Kyiv: Fakt, 2008), 5. 
Scholars today underline that Lesia Ukrainka represented a "phenomenon of female genius" 43 and "uniqueness." 44 The main point here concerns her outstanding talent, incredible willpower, broad worldview, European thinking, and deep national self-awareness, etc. 45 The extraordinary personality of Qiu Jin is today seen in a similar way. Jen Kucharski, for instance, remarks that

her legacy is far richer and more complicated than being a female revolutionary martyr... Qiu Jin was a well-educated and prolific writer, a self-proclaimed knight-errant, an outspoken critic of the Qing Dynasty and traditional Confucian ideals, a fervent supporter of women's rights, ... a revolutionary martyr, a gifted poet... ${ }^{6}$

The diversity of the talents and the wide fields of self-expression of both poetesses create grounds for a broad and comprehensive comparison of the two, but within the objectives of the article it will be focused on those aspects that form the concept of the national heroine in China, which become countercurrents for the Chinese perception the works of Lesia Ukrainka. These aspects are revolution, nationalism, and feminism. ${ }^{47}$

\section{Revolution}

Qiu Jin was canonized in China as the first woman revolutionary. At the age of 29 she shocked the patriarchal society of the Celestial Empire, leaving her family and children in return for studying in Japan and continuing her revolutionary activities. In Tokyo, she became close with her progressive-minded compatriots and finally absorbed the idea of the national liberation of the Chinese from the oppression of the Manchu Qing dynasty. Qiu Jin took an active part in the work of revolutionary communities: Sānhéhui (the Triad in Tokyo, 1905), Tóngménghui (the Revolutionary Alliance in Tokyo, 1905), Guāngfü hui (the Restoration Society in Shaoxing, 1905). $4^{8}$ She actively addressed likeminded people with passionate speeches and wrote poems filled with revolutionary content. In her life and work, Qiu Jin constructed her own masculine identity as a

43 Nila Zborovska, Moia Lesia Ukrainka: Esei [My Lesia Ukrainka. Essays] (Ternopil: Dzhura, 2002), 16.

44 Mariia Karmazina, Lesia Ukrainka (Kyiv: Vydavnychyi dim “Alternatyvy,” 2003), 10.

45 The poetess's contemporaries did not deny this either. For instance, Mykhailo Pavlyk in a letter to Mykhailo Drahomanov (January 1892) called her a woman of genius.

46 Jen Kucharski, "Qiu Jin: An Exemplar of Chinese Feminism, Revolution, and Nationalism at the End of the Qing Dynasty," New Views on Gender 17 (2016): 94.

47 Kucharski, “Qiu Jin,” 94.

48 “Qiu Jin (c. 1875-1907),” Encyclopedia.com, 2020, accessed October 18, 2021, https:// www.encyclopedia.com/women/encyclopedias-almanacs-transcripts-and-maps/qiujin-c-1875-1907. 
woman warrior. According to Women in World History: A Biographical Encyclopedia, "she also adopted a revolutionary style to match her revolutionary zeal. With her Japanese sword, her practice of the martial arts, and her man's attire, she defied the conventional stereotype of a woman. ${ }^{49}$

However, it is worth noting that the image of the female warrior has been cultivated in Chinese history and literature for over 5000 years. As Xiaolin Li states:

Both in ancient and modern times, numerous literary and artistic works portray these historical and fictional women warriors... No matter how educated or where they are located, all Chinese women know the names of such heroes as Mu Lan Hua or Hong Yu Liang..$^{50}$

Dressing in men's clothing (and, in fact, the acquisition of an external masculine identity) became a ritual in China for women who joined the military or liberation struggles. Qiu Jin did not avoid this "ritual," although in her rendition it acquired a new meaning - a demonstration of the strength, will and resilience of an emancipated woman on an equal footing with men.

These circumstances explain the organic entry of the masculine image of Lesia Ukrainka into Chinese cultural space. Chinese researchers only briefly mention her illness in biographical commentaries, avoiding the "Great Patient paradigm." ${ }^{51}$ Instead, they desperately attempt to maximize the spirit of resistance and willpower of the "ardent revolutionary." Of course, the influence of Soviet criticism played a great role, but the special sense of the masculine in Lesia's poetry, which attracted the attention of Chinese translators, should also be noted. Nila Zborovska defined this sense as "specifically a female complex of masculinity, which is manifested not in external power effects, but imperceptibly from the outside, as an individual spiritual choice." ${ }^{2}$ In the poetess's poetic palette, this is conveyed by the ideologeme of the "word-weapon," which expresses the incredible strength of spirit and disobedience. The lyrical heroine "uses the word as a spiritual sword (italics mine. - N. Z.), but a real sword causes suffering of the soul..."53

In Chinese cultural space of the zoth century the images of word and weapon are clearly distinguished. This can be seen in the poetic world of Qiu Jin, where images of

49 “Qiu Jin (c. 1875-1907).”

50 Xiaolin Li, "Chinese Women Soldiers: A History of 5,0oo Years," National Council for the Social Studies, 1994, accessed October 18, 2021, http://www.socialstudies.org/sites/ default/files/publications/se/5802/580201.html.

51 Oksana Zabuzhko critically noted: “The 'Great Patient' paradigm is in fact nothing more than a form of colonial culture's reaction to the 'internal dissent' of its daughter [Lesia Ukrainka] - a kind of Ukrainian version of The Taming of the Shrew." See Zabuzhko, Notre Dame D’Ukraine, 83.

52 Zborovska, Moia Lesia Ukrainka, 86.

53 Zborovska, Moia Lesia Ukrainka, 89. 
the sword and book are pervasive. They symbolize, respectively, military victory and education (knowledge), as two ways of fighting for the self-determination of a nation. If in the early works of Qiu Jin motifs of a struggle for enlightenment prevailed, over time her protest became more persistent, the poetess realizing that the confrontation would be difficult, and to be armed only with words would not suffice for victory. Eventually, her life ${ }^{54}$ and poetic works became filled with images of precious swords, daggers, and steel, which would all inevitably shed blood in the struggle for independence (for example, in the poems "Băojiàngē" (The Precious Blade Song), "Hóngmáo dāogē" (The Red-Bearded Men’s Dagger Song), "Jiàngē” (The Blade Song), "Băodāogē" (The Precious Dagger Song), and many others).

Thus, if over time the faith of Lesia Ukrainka's lyrical heroine disappears and perhaps stops before an inner caution about the probable social consequences of the use of the "word-weapon," in Qiu Jin's poetry - to the contrary - it intensifies.

Particular mention should be made of the Chinese translation of Lesia Ukrainka's poem "Slovo, chomu ty ne tverdaia krytsia," where the translator Mai Xinhe uses vivid images of Qiu Jin's late poetry and therefore promotes the perception of Lesia Ukrainka primarily as a woman warrior. Thus, in the line "Oh word, why art thou not like tempered steel, / Which in the battle gleams with vengeful zeal?" 55 the image of steel is reproduced by the token bishǒu, which is a part of the Chinese idiomatic expression chengy $u^{56}$ - "to unroll a map to reveal a dagger" (tú qióng b̌̌shǒu xiàn), and is used by Qiu Jin in the poem "Băodāogē":

\section{Have you not seen Jing Ke coming as an assassin-retainer to Qin? \\ The map completely unrolled, the foot-long dagger had been exposed?57}

In addition, in translating the line "The blade will ring against the iron yoke" 58 in the poem "Slovo, chomu ty ne tverdaia krytsia" into Chinese, Mai Xinhe also used a

54 Qiu Jin regularly carried a sword or a knife and made much show of her skills in their use. Many are the reports of her performances of martial arts sword dances. She was not averse to more aggressive uses of knives either. See Louise P. Edwards, Women Warriors and Wartime Spies of China (Cambridge: Cambridge University Press, 2016), 52. Mai Xinhe, "Wukelanyingka shi sishou," 135. ("Wǒ dehuà, nǐ wèishéme bù biàn chéng / bǐshǒu de tóng nàyàng jiānyìng," translated by Percival Cundy.)

56 Chengyu are a type of traditional Chinese idiomatic expression, most of which consist of four characters. Chengyu were widely used in Classical Chinese and are still common in vernacular Chinese writing and in the spoken language today.

57 "Jinxiandai Shiren. Qiu Jin Shiciji [Modern Times Poets. Selected Works]," Geren Tushuguan, 2020, accessed October 18, 2021, http://www.36odoc.com/ content/19/1217/o8/2012175_880254857.shtml. ("Bù guān Jingkē zuò qín kè, tú qióng bǐshǒu xiàn yíng chî," translated by Yuri Pines.)

58 Mai Xinhe, "Wukelanyingka shi sishou," 136. ("Băojiàn dīngdāng, liàokào fěnsuì," translated by Percival Cundy.) 
ideologeme of Qiu Jin's mature poetry - băojiàn (the precious blade), which the Chinese poetess considered to be an instrument not of a verbal, but of a liberation struggle, devoting several poems, e.g., "Băojiàngē, Băojiànpiān” ("The Precious Blade Chapter"), etc. to the precious blade.

Thus, the translation of the above-mentioned poetry played a complementary role: it not only actualized the semantic fields of these Chinese symbols, but also synthesized them in a new meaning.

\section{Nationalism}

National liberation issues intersect in the works of Qiu Jin and Lesia Ukrainka. American researcher Hu Ying underlines, that in essays written by her revolutionary colleagues, Qiu Jin is presented as a martyr simply "for an explicitly nationalist cause."59 Drawing on Hu Ying's research, Jen Kucharski pointed out that after the Cultural Revolution "the Chinese Communist Party used Qiu Jin as a symbol of 'revolutionary nationalism'..." ${ }^{\circ}$ The grounds for this statement are the civic lyrics of Qiu Jin with their pervasive anti-Manchurian (and more broadly - "anti-foreign") motifs. The authoress condemns the humiliation of Chinese national dignity by the Manchu authorities and at the same time criticizes her compatriots who have come to terms with slavery, for instance in the poem "Shūwú liètǔyuè" (Grieving the Hero Wu Yue):

The Kunlun mountain range recalls beloved sons, for more than two hundred years the Chinese voices are dumb.

Being downcast and walking in foreign garments, filthy skunks disgracing their forefathers. ${ }^{61}$

Analyzing the political poems of Qiu Jin, Tatiana Zaiats rightly notes that the poetess "was alien to narrow nationalism, but it is natural that at that time her patriotic aspirations often took on an anti-Manchu ... form." ${ }^{62}$ According to Zaiats's interpretation, the national essence of Qiu Jin's poetry was expressed in a wide range of patriotic motifs, where the condemnation of foreign enslavement was only one of them. Similar considerations are valid for the works of Lesia Ukrainka, which have influenced the translation repertoire of her civic lyrics in China.

The national fullness of the Ukrainian poetess's works was aptly defined by Yevhen Malaniuk, who noted:

59 Ying Hu, "Gender," 127.

6o Kucharski, "Qiu Jin," 106.

61 "Jinxiandai Shiren."("Kūnlún yī mài chuán jiāozì,/èrbăi yú nián hàn shēng š̃./Dītóu yìzú hú yīguān,/xīngshān wū rén zǔzōng chî," translated by Olha Vorobei.)

62 Tatiana Zaiats, Qiu Jin: Zhizn i Tvorchestvo (1875-1907) [Qiu Jin: Life and Works, 18751907] (Vladivostok: Izd. Dalnevostochnogo un-ta, 1984), 77. 
Lesia Ukrainka is already a national phenomenon (italics mine. - Ye. M.). This is a manifestation of the nation - on the eve of its political revival and late cultural self-awareness. ${ }^{63}$

Unlike Qiu Jin, who expressed her ideas declaratively, sometimes mixing poetic and journalistic discourses, ${ }^{6}$ the Ukrainian poetess often used plots of world literature stories and made the most out of allegorical means. In ancient material, she always found a national aspect, "which could generate patriotic feelings and literary motifs." 65 A striking example is the dramatic poem "Vavilonskyi polon," translated into Chinese in 1921.

The story about the Babylonian captivity of the Jewish people, according to Antin Kharchenko, became a universal symbol for "the suffering and destruction of every conquered and oppressed nation.”6 Chinese translator Mao Dun noted the deep socio-historical resonance of Lesia Ukrainka's poem, in line with the Chinese reality of the early zoth century, and presented it as a landmark work of "the literature of enslaved peoples" (mentioned in the introduction). At the same time, the leitmotifs of the dramatic poem "Vavilonskyi polon" evoke strong associations with the civic lyrics of Qiu Jin, placing its translation in the context of Chinese literature. Such a leitmotif is meant to expose the slavish existence of enslaved peoples and the motivation to fight for freedom, for instance in the speech of the singer Eleazar:

To suffer chains is inhuman shame, to forget them unbroken yet greater ignominy.

Two paths we have, death or disgrace, till we find a way to Jerusalem. ${ }^{67}$

Another common leitmotif that reveals the patriotic themes of the poetry of Lesia Ukrainka and Qiu Jin is mental pain and almost physical suffering for the fate of the native land and people. In her letter to Mykhailo Pavlyk, Lesia Ukrainka wrote:

63 Malaniuk, "Do rokovyn," 201.

64 According to Tatiana Zaiats, Qiu Jin was a supporter of a "revolution in the field of poetry," which was proclaimed in the end 19th century by Tan Sitong and Huang Zunxian. In her poems the poetess quite freely used "non-poetic" expressions related to the themes of emancipation of society, socialization of women, etc. See Zaiats, Qiu Jin, 84 .

65 Iryna Pelenska, "Do zenesy 'Ifihenii v Tavrydi' Lesi Ukrainky [On the Genesis of 'Iphigenia in Tauris' by Lesia Ukrainka]," in Lesia Ukrainka. 1871-1971 (Philadelphia, 1971), 181.

66 Antin Kharchenko, "Nevolia i Ruina [Slavery and the Ruin]," Lesia Ukrainka. Entsyklopediia zhyttia i tvorchosti, 2020, accessed October 18, 2021, https:// www.l-ukrainka.name/uk/Studies/SlaveryAndRuine.html.

67 Five Russian Plays, 16. ("Terpit kaidany - to nesvitskii sorom, / zabut ikh, ne rozbyvshy, - hirshyi styd. / Nam dva shliakhy: smert abo ganba, poky / ne znaidem schliakh v Yerusalym," translated by Carl Eric Bechhofer.) 
"Shame and pity for my country just festers me... and I did not realize that in my soul there is such a great store of spite." 68

This confession also characterizes the works of Qiu Jin. It is important that both poetesses, deeply concerned with harsh reality, did not fall into despair and helplessness. Instead, they mixed a palette of feelings ranging from suffering to resistance, expressing them in the intersecting poetic symbol of tears, which is undoubtedly based on resignation, i.e., the flat refusal of obedience, an awareness of the necessity to resist the grief.

The image of fiery tears is quite vivid in the works of Qiu Jin: the poetess, while in Japan, worries about the fate of her Motherland and sheds bitter, ardent, and bloody tears leaving China. For instance, in the poem "Mănjiānghóng. Juān." (All River Red. Cuckoo):

I am addressing a question to Heaven

if the waning Moon can turn the full one?

Heaven bleeds with crying. ${ }^{69}$

It is noteworthy that the poems of Lesia Ukrainka selected by Chinese translators contain an intersecting image of fiery and bloody tears, which correlates with the image of Qiu Jin as a revolutionary woman who renounces the useless tears of powerlessness. Especially noteworthy of attention is "Slozy-perly," a series of poems dedicated to Ivan Franko:

O hot burning tears! They burn deep in my soul:

The fiery traces they leave are eternal. ${ }^{70}$

Thus, for both poetesses, there is a common image of ardent, bloody tears as a means of forming a protest victory, a willingness to sacrifice themselves, but in no case to put up with a sense of hopelessness in the face of cruelty and injustice in the world.

The process of drying up tears is a traditional gender initiation and prerogative of men who focus on the behavioral scale of the Nietzschean superman. The Italian writer Gabriele D’Annunzio, whose work Lesia Ukrainka found interesting, noted in his last novel Forse Che Si Forse Che No (Possibly Yes, Possibly No), that non-female tears are the tears of a warrior-traveler. They do not flow because of torment, but “...because of fury. In a fume they respond to the fumes of a storm. The wind of victory

68 Lesia Ukrainka, "Lyst do M.I. Pavlyka vid 19.04.1895 r."[Letter to M.I. Pavlyk, April 19, 1895], in Lesia Ukrainka. Zibrannia tvoriv u 12 tomakh, vol. 10 (Kyiv: Naukova dumka, 1978), 297.

69 "Jinxiandai Shiren." ("Wèn qīngtiān quē yuè kě cháng yuán? Kōng tí xuè," translated by Olha Vorobei.)

70 Mai Xinhe, "Wukelanyingka Shi Sishou," 133. ("Ō, yănlèi, tóngnián băoliú xiàlái de rèqíng,/ tā shř wǒ zhěng ge xin er dōu zài ránshāo," translated by OlhaVorobei.) 
will dry them up."71 Perhaps, subconsciously referring to the masculinized image of a militant woman embedded by Qiu Jin, Ge Baoquan translated the line in the poem "Mii shliakh" - "Common tears are not so bitter"72 - precisely as a process of drying-out tears: "Our solidarity would dry-out the tears,"73 thereby essentially changing the context presented by the Ukrainian poetess.

Another intersecting motif that completes the construction of Lesia Ukrainka as a woman liberator and revolutionary in the worldview of the Chinese reader is a collective lament of the disadvantaged, whose savior is each poetess. The motif of the bitter tears of the Chinese people sounds in many poems of Qiu Jin, for instance in Shūwú liètǔyuè:

I bid you all to lament bitterly to summon up the dead men's spirits. ${ }^{74}$

Thus, the poetess's personality in this context becomes the collective personality of the nation, and it is difficult to determine where she complains about her own suffering and where she mourns national grief - her person is intertwined with the nation. The Chinese translations of Lesia Ukrainka's poems convey the whole semantic palette of these common, folk tears, as in the poem "Skriz plach, i stohin, i rydannia...": "Laments, groans are all around, / Irresolute, faint challenges," 75 where in his translation Ge Baoquan used almost the same lexical units: "laments and deep sighs are all around, / the outcries are lacking courage." ${ }^{76}$ At times this is even intensified, as in the translation of "Slozy-perly" by Mai Xinhe, where in the line "My Ukraine! I weep for you many a tear..." 77 the translator on purpose deepens the poetess' grief for the fate of Ukraine by comparing tears with a rough torrent: "My Ukraine! I stand before You and cry a torrent of tears." 78

In such a way, the collective lamentation of both poetesses is involved in the structure of the text in order to strengthen the mode of experience. The images of tears and lamentation create a picture of despondency and unspeakable sadness. But collective crying is seen as a guarantee of the unity of the underprivileged, and thus -

71 Gabriele D’Annunzio, Forse Che Sì Forse Che No (Milano: Mondadori, 1959), 113.

72 Lesia Ukrainka, Zibrannia tvoriv, vol. 1, 83. ("Bo ne taki vzhe hirki slozy - spilni," translated by Olha Vorobei.)

73 Ge Baoquan, "Wukelanyingka Shi Wuzhang," 101. ("Yănlèi măshàng jiù huì yīnwèi wǒde tóngqíng héjié," translated by Olha Vorobei.)

74 “Jinxiandai Shiren." ("Wǒ lìng tòngkū wèi zhāohún,” translated by Olha Vorobei.)

75 Lesia Ukrainka, Spirit of Flame, trans. Percival Cundy (Westport, Conn.: Greenwood Press, 1971), 55 .

76 Ge Baoquan, "Wukelanyingka Shi Wuzhang [Five Poems by Lesia Ukrainka]," Sulian Wenyi 33 (1948): 106. ("Dàochù dōu shì kū shēng hé shēnchén de tànxí,/jiàohăn shēng bìng bù yǒnggăn,” translated by Olha Vorobei.)

77 Lesia Ukrainka, Hope: Selected Poetry, trans. Gladys Evans (Kyiv: Dnipro, 1975), 47.

78 Mai Xinhe, "Wukelanyingka Shi Sishou,” 133. ("Wūkèlán, wǒ zhàn zài nǐ miànqián lèi rú quányǒng," translated by Olha Vorobei.) 
their joint struggle, which becomes a common credo for both Qiu Jin and Lesia Ukrainka.

\section{Feminism}

In the 1990s, in China, as well as in Ukraine, interest in feminist studies increased rapidly, which caused the inclusion of relevant concepts in the further research of female writers' works, including Qiu Jin's and Lesia Ukrainka's. However, it should be noted that Ukrainian literary critics ${ }^{79}$ focused primarily on Lesia Ukrainka's literary texts, searching for a national "feminine code" in them, while researchers of Qiu Jin's works (and not only in China) often preferred her emancipatory ideas in the context of revolutionary struggle. For instance, Hu Ying notes: “What makes Qiu Jin a 'true' New Woman is thus her subordination of 'women's liberation' to 'national liberation." ${ }^{80}$ The sociological approach also affected comparative studies. Thus, Zhu Hong and He Zhongchang, professors at Wuhan University came to a quite general and tendentious conclusion that "Qiu Jin, like Lesia Ukrainka, fought all her life for the liberation of women from feudal oppression." ${ }^{81}$ The harmonization of the views of Qiu Jin and Lesia Ukrainka on the "women's issue" was not limited only by socio-political issues but can be traced in poetic concepts as well.

According to Jen Kucharski, “Qiu Jin's rich legacy comes as much from her unique feminism, willingness to act, and bold personality as it does from her essays and poetry." ${ }^{\prime 2}$ She understood the idea of gender equality primarily in the ability of women to overcome the boundaries of traditional gender roles and, along with men, to participate in deciding the fate of the Motherland. In the poem "Mănjiānghóng" (Crimson Flooding into the River) she says:

Despite our abilities, men hold the highest ranks

But while our hearts are pure, those of men are rank

My insides are afire in anger at such an outrage

How could vile men claim to know who I am?83

See Vira Aheieva, Poetesa zlamu stolit: Tvorchist Lesi Ukrainky v postmodernii interpretatsii [A Poetess at the Turn of Centuries: Lesia Ukrainka's Writings in Postmodern Interpretation] (Kyiv: Lybid, 1999); Roman Veretelnyk, "Feminizm u dramaturhii Lesi Ukrainky [Feminism in Lesia Ukrainka's Dramaturgy]," Suchasnist 2 (1991): 29-37; Tamara Hundorova, Proiavlennia slova. Dyskursiia rannoho ukrainskoho modernizmu. Postmoderna interpretatsiia [Manifestation of the Word. Discursion on Ukrainian Early Modernity. Postmodern Interpretation] (Lviv: Litopys, 1997); Pavlychko, Dyskurs modernizmu, etc.

$80 \quad$ Ying Hu, "Gender," 133.

81 Zhu Hong and He Rongchang, "Lesia Ukrainka v Kytai," 162-63.

82 Kucharski, "Qiu Jin," 106-o7.

83 "Jinxiandai Shiren." ("Shēn bùdé, nán'ér liè; xīn què bǐ, nán’ér liè! Suàn píngshēng gāndăn, bù yīn rén rè, sú fū xiōngjīn shéi shí wǒ," translated by Michael A. Mikita.) 
Qiu Jin considered the education of Chinese women to be the key to women's independence. In 1906 she taught at the Míngdào (Bright Way) Women's School in Shaoxing, and in 1907, together with like-minded people, she began publishing Zhōngguó nübào (Chinese Woman Magazine) in Shanghai. On its pages, Qiu Jin actively criticized the brutal tradition of foot binding, as well as advocating for women's rights to free marriage and education. In the foreword to the first issue of the journal she called on her compatriots to end the present darkness and ignorance:

Isn't it better to break out of the realm of darkness towards the light than to risk your life by obeying the law of life? The sacred lantern will lead millions of people to the other shore, isn't that the highest mission? ${ }^{84}$

Motives of Prometheism, inherent in the worldview of Lesia Ukrainka, can be traced in this statement. However, it should be emphasized that the ideas of women's emancipation in Lesia Ukrainka's worldview were not overt. Nila Zborovska, basing her views on Klyment Kvitka's memoirs, noted that Lesia Ukrainka acknowledged the idea of women's equality, but did not follow the feminist movement, did not like women's journals, clubs, etc. ${ }^{85}$ However, Professor Roman Veretelnyk justifiably called Lesia Ukrainka an "intellectual feminist," 86 noting the "extraordinary women of great strength of will and intellect" in her work and underlining that in her article "Novye perspectivy i starye teni" (New Perspectives and Old Shadows," 1900) the author comprehensively covered the "women's issue" in European literature. In terms of the depth of material analysis and the logic of its coverage, Mariia Karmazina considers this work on par with other classic works of feminist criticism, in particular Virginia Woolf's essay A Room of One's Own. ${ }^{87}$ In her article, Lesia Ukrainka also drew attention to the issues her Chinese counterpart was concerned about - the education and socialization of women, which are key to women's economic independence. However, the essential difference of Lesia Ukrainka's position is her exceptional attention to "extraordinary," "talented" women, their recognition, and acquired rights.

According to the conclusion of Solomiia Pavlychko, two positions can be delineated in the views of Lesia Ukrainka: on the one hand, she speaks of the naturalness of the feminist idea, which does not require proof, and on the other - indicates the rather sad predicament of women and the need to fight for their rights. ${ }^{88}$ This influenced the poetess's poetic concept. All of Lesia Ukrainka's heroines are strong women who

84 Jin Qiu, "Zhongguo Nü Bao Fakanci [Foreword to Chinese Woman Magazine]," trans. Olha Vorobei, Weijiwenku, 2020, accessed October 18, 2021, https://zh.m.wikisource. org/zh-hans/中國女報發刊詞.

85 Zborovska, Moia Lesia Ukrainka, 8 .

86 Veretelnyk, "Feminizm u dramaturhii," 29.

87 Karmazina, Lesia Ukrainka, 274-75.

88 Pavlychko, Dyskurs modernizmu, 73-74. 
are in "cataclysmic crises and disturbing circumstances," ${ }^{89}$ and lyrical heroines are often masculinized, ${ }^{90}$ embodying the idea of resistance. However, the poetess sometimes expresses quite radical thoughts, accusing her compatriots of self-denial in favor of men. In the poem "Zhinochyi portret" (A Woman's Portrait) Lesia Ukrainka reproaches the "honest" and "good" woman with voluntarily obeying the laws of humiliating patriarchal marriage and becoming a slave to her husband:

Not the body you sold, but your soul,
your talent and mind you sent into captivity,
condemned to lifelong drudgery, -
so bitterly and sweetly you feel this rigidity.

This theme was extremely relevant for Qiu Jin as well. In her essay "Jìnggào zimèimen" (To My Sisters), she raised the issue of the inaction of the Chinese women who had come to terms with slavery and wanted no changes. Qiu Jin was indignant at her compatriots who mocked their own bodies to please their men: they bound their feet, combed their hair tightly, and covered their faces with a thick layer of powder and blush. Qiu Jin makes a conclusion similar to Lesia Ukrainka's:

In each and every case, men occupy a position of authority and women occupy a position of slavery. Because they want to depend on others, they themselves do not have the slightest desire for independence. These prisoners locked up in their inner apartments do not have even the slightest inclination of their own suffering! ${ }^{22}$

Typological aspects of the gender thinking of both poetesses are reflected in similar poetic motives and images. It is worth taking into consideration the opinion of Pavlychko that "in the context of Ukrainian literature at the turn of the (2oth) century, the feminine and the feminist have become synonymous, and a source for modernity." 93

89 Veretelnyk, "Feminizm u dramaturhii," 29.

90 Solomiia Pavlychko emphasizes that all the images of Lesia Ukrainka's dramas are "variations on the theme of women's tragedy," ignoring the strength of character and will of the portrayed heroines.

At the same time, the researcher is not entirely convincing in her interpretations of the feminist images (e.g., Rachel, Joan of Arc, Ophelia, etc.) of Lesia Ukrainka's lyrics as tendentious ones.

91 Lesia Ukrainka, Zibrannia tvoriv, vol. 1, 344. ("Ne tilo ty, a dushu prodala, / svii khyst i rozum viddala v nevoliu, / u katorhu dovichnu zavdala, - / i hirko i solodko tobi do boliu," translated by Olha Vorobei.)

92 Jin Qiu, "To My Sisters," in The Red Brush: Writing Women of Imperial China (Cambridge: Harvard University Asia Center, 2004), 797.

93 Pavlychko, Dyskurs modernizmu, 87. 
This point of view is also true for Chinese literature of the same period. New "women's themes" in fiction discourse and women's interpretations of existing material (e.g., mythological images, classical plots and motifs) were a way of "expressing the spirit of the time's urgency" and were often seen in the vein of feminism. Two new symbolic motifs can be traced in the works of Qiu Jin and Lesia Ukrainka - "female friendship," and "dedication to a hopeless cause."

Professor Charles Patrick Fitzgerald mentioned that in Chinese traditional poetry

friendship fills the place which love occupies in European poems, and, as the emotional crisis of friendship is the moment of separation, parting from a friend inspires many of the best poems in China. ${ }^{94}$

It is important that this statement was valid exclusively regarding male companionship, which was endowed with a special "emotional value." Poets often wrote poems to distant friends to tell them about their grief. Fellowship between women was impossible because of their solitary lives, which were strictly regulated by the norms of patriarchal morality. Thus, the theme of friendship was not included in the repertoire of traditional women's lyrics. Qiu Jin broke this tradition by creating a series of poems-messages to her like-minded friends (both men and women). Furthermore, according to the research of Tatiana Zaiats, "intimate emotional impulses [of the author], confessions of love are peculiar only to verses addressed to femalefriends." 95 Often such messages reproduce the sad mood of the lyrical heroine and are characterized by emphasized aesthetics. For example, in the poem "Jì Chéngmèi" (Sent to My Sister Cheng) Qiu Jin uses images and symbols of traditional landscape poetry:

Bright jinlin ${ }^{96}$ vanished into the space, wild geese ${ }^{97}$ stood still, boundless grief took hold of my soul, and I am clasping the blanket tight.

In the inner sanctum just the luminaire is by my side, At least the Moon ${ }^{8}$ above the banisters gives my soul light. I hear rustling leaves falling on the empty stairs outside, the dew of my sorrow I entrust to the silent zither.

94 Charles Patrick Fitzgerald, China: A Short Cultural History (London: The Cresset Press, 1988), 344.

95 Zaiats, Qiu Jin, 93.

96 The bright jinlin (or unicorn) is a mythical animal, the embodiment of absolute good. Its appearance is a happy sign, and its disappearance, respectively, a sign of the loss of hope for the better. According to Tatiana Zaiats, the phrase jinlin also means "velvet scales" and symbolizes a letter to a related soul.

97 Wild geese symbolize letter, news, or tidings.

98 Moon - a symbol of the reunion of relatives and friends who are separated (they can simultaneously contemplate the moon from different parts of the Celestial Empire). 
With blooming brunch trying to reach Cheng the sister, Cannot stand the sounds of the battledores at evening riverside. ${ }^{99}$

The theme of women's friendship is present in the epistolary works of Lesia Ukrainka. The poetess's close emotional relationships with Olha Kobylianska is probably the most discussed fact in post-Soviet Lesia Ukrainka studies. These relations have given rise to a number of interpretations: beginning with a "women's platonic romance" ${ }^{100}$ and ending with "lesbian fantasies." ${ }^{101}$ Within the framework of this research, the opinion of Vira Aheieva about the correspondence of women writers is quite convincing. She notes that it is an example of an "openness of women's selfdisclosure, very exceptional in its intimate sincerity evidence of friendship between women writers, which allowed the destruction of common and ... stylistic stereotypes." ${ }^{102}$ The same can be said about Lesia Ukrainka's poem-message "Schliu do tebe malyi sei lystochok..." addressed to Oleksandra Sudovshchykova. The poem attracted the attention of Chinese translators through its emotional and psychological echoing with the candid poetry of Qiu Jin:

Right, my dear, I am so lugubrious,

My fate made me so dolorous,

It is the best bondage for the hopes and joy,

it led all my intentions to the destroy....

Can the sorrow be so unamused?

This question sending for Your muse, -

Let her like a cuckoo in the meadow,

liven up your dolorous fellow. ${ }^{103}$

Another common motif in the works of Qiu Jin and Lesia Ukrainka is "dedication to a hopeless cause," which has mythological roots in both poetesses' works. Speaking

99 "Jinxiandai Shiren." "Jǐn lín yăo yăo yàn chénchén, wúxiàn chóuhuái dú yǒng qīn. Guī nèi wéi yú dēng zuò bàn, lán qián xìng yǒu yuè zhīxīn. Shù shēng luòyè míng kōng qì, yīdiăn wúliáo tuō sù qín. Shū yú huāzhī chēng zǐmèi, bùkān yáo tīng mù jiāng zhēn," translated by Olha Vorobei.)

100 Tamara Hundorova, Femina melancholica. Stat $i$ kultura $v$ hendernii utopii Olhy Kobylianskoi [Femina Melancholica. Sex and Culture in the Gender Utopia of Olha Kobylianska] (Kyiv: Krytyka, 2002), 53.

101 Pavlychko, Dyskurs modernizmu, 86.

102 Aheieva, Poetesa zlamu stolit, 83-84.

103 Lesia Ukrainka, Zibrannia tvoriv, vol. 1, 224. ("Tak, ya smutna teper, moia liuba, / Zasmutyla mene moia dolia, / Vona mriiam naikrashchym nevolia, / Vona vsim moim zamiram zhuba. ... / Ta chy ye nerozvazhnaia tuha? / Se pytannia ya shlyu tvoii muzi, - / Khai vona, yak zozulenka v luzi, / Zveselyt tvoho smutnoho druha," translated by Olha Vorobei.) 
about Lesia Ukrainka, this motif was dramatically voiced in the poem "Contra spem spero!" where the author reinterprets the image of Sisyphus, projecting it onto her real self. If for the mythological hero rolling a stone up the mountain is a punishment (conscious useless work), then from the point of view of Lesia Ukrainka's heroine the hard work generates faith in the realization of the impossible and encourages struggle. This optimistic motif can also be traced in the drama Orfeieve chudo (The Orpheus Miracle). In various variations, it is also presented in the early poems "Nadiia" and "Mii schliakh," which have been repeatedly translated in China. According to research conducted by Halyna Levchenko, Lesia Ukrainka's early lyrics are the reflection of the poetess's romantic worldview, which formed the image of a lyrical heroine who "consciously chose her path of competition and romantic confrontation of fate." ${ }^{104}$ This type of lyrical heroine is inherent in the works of Qiu Jin as well. The motif of "dedication to a hopeless cause" in her works is associated with the image of the mythical Jingwei bird. ${ }^{105}$ This motive is meaningful in Qiu Jin's semi-biographical tanci ${ }^{106}$ fiction Jingwèishí (1905-1907; Stones of Jingwei). It tells the story of five female friends who escape from their repressive families to study abroad in Japan for the sake of liberating Chinese women and China. The image of the Jingwei bird and the motif of the "dedication to a hopeless cause" can be traced in the poem "Jiànyuè" (Viewing the Moon) and the author's articles. According to Xian Wang, "Qiu Jin used the Jingwei bird as a romantic symbol that encouraged her to dedicate herself to changing the world despite insurmountable obstacles." ${ }^{107}$

\section{Conclusion}

Summing up the research, the translation of Lesia Ukrainka's poetic works in China during the 2oth century reveals the ideological and aesthetic factors of the reception of the image of the Ukrainian artist in China. The choice of texts and the reproduction of the image-emotional system of Lesia Ukrainka's poetry made by translators reveals a much deeper and more complex endeavor than the one-sided assessments of Chinese literary critics, who were motivated by ideological factors.

The work of the revolutionary poet Qiu Jin played an important role in formation of the artistic image of Lesia Ukrainka in China. The poetic worlds of both artists reveal spheres of intersection and complementarity. Against the background of the

104 Levchenko, "Semiosfera liryky," 106.

105 The ancient Chinese myth Jingwèi tiánhăi (The Jingwei Bird Fills the Sea) tells of how Jingwei, the daughter of God Yandi, drowned in the East Sea. She was reincarnated as a bird and was determined to fill the sea with pebbles and branches. The myth connotes the meaning of tireless dedication to a hopeless cause. See Xian Wang, "Flesh and Stone," 127. Tanci was originally an oral performance genre from southern China that was popular with female audiences. In late imperial China, especially during the late Qing, women from gentry families participated in writing prosimetric tanci novels. See Xian Wang, "Flesh and Stone," 126.

107 Xian Wang, "Flesh and Stone," 128. 
national heroine image formed by Qiu Jin, the Ukrainian poetess appeared in Chinese translations as a strong-willed, steadfast and masculinized liberator with a spirit of militant resistance (the symbol of the sword) and heartache for the fate of her people (the symbol of burning bloody tears). The feminist code of the image of Lesia Ukrainka is expressed in the emphasized sincerity of sisterhood relationships and unfailing faith in the realization of dreams despite insurmountable obstacles. The individual motifs of Lesia Ukrainka's poetry complement this image with a "specifically female complex of courage," which concentrates on the power of the spiritual sword (the ideologeme of theword-weapon) and the character of an extraordinary woman-intellectual (references to images and mythologemes of European cultures).

\section{Bibliography}

Aheieva, Vira. Poetesa zlamu stolit: Tvorchist Lesi Ukrainky v postmodernii interpretatsii [A Poetess at the Turn of Centuries: Lesia Ukrainka's Writings in Postmodern Interpretation]. Kyiv: Lybid, 1999.

Aheieva, Vira. Zhinochyi prostir: Feministychnyi dyskurs ukrainskoho modernizmu [Female Space: The Feminist Discourse of Ukrainian Modernism]. Kyiv: Fakt, 2008.

Berman, Art. Preface to Modernism. Urbana: University of Illinois Press, 1994.

D’Annunzio, Gabriele. Forse Che Sì Forse Che No. Milano: Mondadori, 1959.

Edwards, Louise P. Women Warriors and Wartime Spies of China. Cambridge: Cambridge University Press, 2016.

Fitzgerald, Charles Patrick. China: A Short Cultural History. Reprint. London: The Cresset Press, 1988.

Five Russian Plays, With One from the Ukrainian. Translation and introduction by Carl Eric Bechhofer. Internet Archive, 2020. Accessed October 18, 2021. https://archive.org/details/ fiverussianplaysoorobe.

Ge, Baoquan. "Ukrainska literatura v Kytai [Ukrainian Literature in China].” Translated by Ivan Chyrko. Vsesvit 8 (1987): 139-40.

Ge, Baoquan. "Wukelan Wenxue Zai Zhongguo [Ukrainian Literature in China]." Zhongguo Fanyi 3 (1988): 37.

Ge, Baoquan. "Wukelanyingka Shi Wuzhang [Five Poems by Lesia Ukrainka]." Sulian Wenyi 33 (1948): 101-11.

Habermas, Jurgen. "Modern - nezavershennyi proekt [Modernity - An Incomplete Project]." Voprosy filosofii 4 (1992): 40-52.

Hu, Ying. "Gender and Modern Martyrology: Qiu Jin as Lienü, Lieshi, or Nülieshi." In Beyond Exemplar Tales: Women's Biography in Chinese History, edited by Joan Judge and Ying Hu, 121-36. Berkeley; Los Angeles; London: University of California Press, 2011.

Hundorova, Tamara. Femina melancholica. Stat i kultura v hendernii utopii Olhy Kobylianskoi [Femina Melancholica. Sex and Culture in the Gender Utopia of Olha Kobylianska]. Kyiv: Krytyka, 2002.

Hundorova, Tamara. Proiavlennia slova. Dyskursiia rannoho ukrainskoho modernizmu. Postmoderna interpretatsiia [The Manifestation of the Word. Discursion on Ukrainian Early Modernity. A Postmodern Interpretation]. Lviv: Litopys, 1997.

Isaieva, Nataliia. Kytaiska zhinocha proza: Reviziia kanonu [Chinese Women's Prose: A Revision of the Canon]. 2nd ed. Kyiv: Logos, 2018.

"Jinxiandai Shiren. Qiu Jin Shiciji (Shoucangban) [Modern Times Poets. Selected works]." Geren Tushuguan, 2020. Accessed October 18, 2021. http://www.36odoc.com/ content/19/1217/o8/2012175_880254857.shtml. 
Karmazina, Mariia. Lesia Ukrainka. Kyiv: Vydavnychyi dim "Alternatyvy," 2003.

Kharchenko, Antin. "Nevolia i Ruina [Slavery and the Ruin]." Lesia Ukrainka. Entsyklopediia zhyttia i tvorchosti, 2020. Accessed October 18, 2021. https://www.l-ukrainka.name/uk/ Studies/SlaveryAndRuine.html.

Khaidapova, Marina. "Ideino-khudozhestvennoe svoeobrazie kitaiskoi tumannoi poezii [The Conceptual and Artistic Peculiarity of Chinese 'Misty Poetry']." Vestnik Buratskogo Gosudarstvennogo Universiteta 8 (2012): 106-09.

Koval, Oleksii. "Yak Rukh 4 Travnia zminyv Kytai [How the May Fourth Movement Changed China]." Ukraine-China, 2019. Accessed October 18, 2021. https://sinologist.com.ua/ koval-o-yak-ruh-4-travnya-zminyv-kytaj/.

Kucharski, Jen. "Qiu Jin: An Exemplar of Chinese Feminism, Revolution, and Nationalism at the End of the Qing Dynasty." New Views on Gender 17 (2016): 94-106.

Levchenko, Halyna. "Semiosfera liryky Lesi Ukrainky [The Semiosphere of Lesia Ukrainka's Lyrics]." Doctor of Philology diss., Ivan Franko State University of Zhytomyr, 2015.

Li, Xiaolin. "Chinese Women Soldiers: A History of 5,00o Years." National Council for the Social Studies, 1994. Accessed October 18, 2021. http://www.socialstudies.org/sites/default/ files/publications/se/5802/580201.html.

Mai, Xinhe. "Wukelanyingka Shi Sishou [Four Poems by Lesia Ukrainka]." Shijie Wenxue 7-8 (1962): 132-39.

Malaniuk, Yevhen. "Do rokovyn Lesi Ukrainky (13.II.1871) [On Lesia Ukrainka's Anniversary (February 13, 1871)].” In Knyha sposterezhen. Statti pro literaturu by Yevhen Malaniuk, 202. Kyiv: Dnipro, 1997.

Murashevych, Kateryna. "Khudozhno-estetychnyi fenomen poezii '4 travnia' v kytaiskii literaturi pochatku 20 stolittia [The Artistic-Aesthetic Phenomenon of May Forth Poetry in Chinese Literatureat the Beginning of the 2oth Century]." Ph.D. diss., Taras Shevchenko National University of Kyiv, 2011.

Mykytenko, Oleh "Ukrainsko-kytaiski literaturni zviazky v yikh istorychnomu rozvytku [SinoUkrainian Relations Within the Scope of Their Historical Development]." In Ukraine China: Ways of Cooperation, 110. Kyiv: MPP “INTEL," 1993.

Ohnieva, Olena. "Kanon Fengliu i osobystyi shliakh Lesi Ukrainky [Fengliu Canon and Lesia Ukrainka's Personal Path]." In Research of Eastern and Western Civilizations, 75-80. Kyiv, 2004.

Pavlychko, Solomiia. Dyskurs modernizmu v ukrainskii literaturi [The Discourse of Modernism in Ukrainian Literature]." 2nd ed. Kyiv: Lybid, 1999.

Pecharskii, Andrii, and Kewen Sun. Antolohiia ukrainskoho ta kytaiskoho pysmenstva. Perekladatski innovatsii u lvivskii "Alma Mater" [An Anthology of Chinese and Ukrainian Belles-Letters. Translation Innovations at the Lviv "Alma Mater"]. Lviv: Ivan Franko National Univetsity of Lviv, 2017.

Pelenska, Iryna. "Do henezy 'Ifihenii v Tavrydi' Lesi Ukrainky [On the Genesis of Iphigenia in Tauris by Lesia Ukrainka].” In Lesia Ukrainka. 1871-1971, edited by Bohdan Romanenchuk, 179-98. Philadelphia, 1971.

Pines, Yuri. "A Hero Terrorist: Adoration of Jing Ke Revisited." Asia Major 21.2 (2008): 29.

"Qiu Jin (c. 1875-1907)." Encyclopedia.com, 2020. Accessed October 18, 2021. https://www. encyclopedia.com/women/encyclopedias-almanacs-transcripts-and-maps/qiujin-c-1875-19o7.

Qiu, Jin. “To My Sisters.” In The Red Brush: Writing Women of Imperial China, edited by Wilt L. Idema and Beata Grant, 797. Cambridge: Harvard University Asia Center, 2004.

Qiu, Jin. "Zhongguo NüBao Fakanci [Foreword to Chinese Woman Magazine]." Weijiwenku, 2020. Accessed October 18, 2021. https://zh.m.wikisource.org/zh-hans/中國女報發刊詞. 
Sorokin, Vladislav. "Literatura novogo Kitaia [Literature of the New China]." In Dukhovnaia kultura Kitaia. Vol. 3, "Literatura. Yazyk i Pismennost," edited by Mikhail Titarenko, 155. Moscow: Vostochnaia literatura, 2008.

Toper, Pavel. Perevod v sisteme sravnitelnogo literaturovediniia [Translation in the System of Comparative Literature]. Moscow: Nasledie, 2000.

Ukrainka, Lesia. “Lyst do M.I. Pavlyka vid 19.04.1895 r. [Letter to M.I. Pavlyk, February 19, 1895].” In Lesia Ukrainka, Zibrannia tvoriv u 12 tomakh. Vol. 10, 297. Kyiv: Naukova dumka, 1978.

Ukrainka, Lesia. Hope: Selected Poetry. Translated by Gladys Evans. Kyiv: Dnipro, 1975.

Ukrainka, Lesia. Spirit of Flame. Translated by Percival Cundy. Westport, Conn.: Greenwood Press, 1971.

Ukrainka, Lesia. Zibrannia tvoriv [Collected Works]. Vols 1, 12. Kyiv: Naukova dumka, 1975, 1979.

Veretelnyk, Roman. "Feminizm u dramaturhii Lesi Ukrainky [Feminism in Lesia Ukrainka's Dramaturgy]." Suchasnist 2 (1991): 29-37. Accessed October 18, 2021. https://diasporiana. org.ua/wp-content/uploads/books/3346/file.pdf.

Veselovskii, Aleksandr. Razyskaniia v oblasti russkogo dukhovnogo stiha [Research in the Field of Russian Clerical Poetry]. Saint Petersburg: Imperatorskaia Akademiia Nauk, 1889.

Wang, Xian. "Flesh and Stone: Competing Narratives of Female Martyrdom from Late Imperial to Contemporary China." Ph.D. diss., Department of East Asian Languages and Literatures of the University of Oregon, 2018.

Zabuzhko, Oksana. Notre Dame D’Ukraine: Ukrainka v konflikti mifolohii [Notre Dame d'Ukraine: Ukrainka in a Conflict of Mythologies]. Kyiv: Fakt, 2007.

Zaiats, Tatiana. Qiu Jin: Zhizn i Tvorchestvo (1875-1907) [Qiu Jin: Life and Works, 1875-1907]. Vladivistok: Izd. Dalnevostochnogo un-ta, 1984.

Zborovska, Nila. Moia Lesia Ukrainka: Esei [My Lesia Ukrainka. Essays]. Ternopil: Dzhura, 2002.

Zhou, Zhonghe. "Ukrainska literatura blyzka ta doroha kytaiskomu narodu [Ukrainian Literature is Close and Dear to the Chinese Nation].” In Ukraine - China: Ways of Cooperation, 110. Kyiv: MPP “INTEL," 1993.

Zhu, Bianzhe. "Wukelan Shixuan [Selected Ukrainian Poems]." Sulian Wenxue 2 (1987): 68.

Zhu, Hong, and Rongchang He. "Lesia Ukrainka v Kytai [Lesia Ukrainka in China].” Vsesvit 3 (1994): 139 .

\section{(2)}

Nataliia Isaieva is a Doctor of Philology, Associate Professor, and Acting Head of the Department of Far Eastern and Southeastern Languages and Literatures of the Institute of Philology at Taras Shevchenko National University of Kyiv. Her sphere of scholarly interests includes the latest research in the field of Chinese modern literature, gender studies in terms of literary criticism, literary and cultural Sino-Ukrainian relations, literary translation, and ethno-national peculiarities of Chinese literary discourse. Dr. Nataliia Isaieva is the author of over 70 articles, a monograph, and textbooks. Her 2018 study Chinese Women's Prose: A Revision of the Canon constituted the first modern application of feminist theory in Chinese literary studies.

Olha Vorobei holds a PhD in philology and is an assistant lecturer at the Department of Far Eastern and Southeastern Languages and Literatures of the Institute of Philology at Taras Shevchenko National University of Kyiv. Her research interests include Chinese literature of the 2oth century, the literary translation of Chinese spoken drama, and issues of the interpretation and perception of Chinese modern literature. She is the author of more than 20 scholarly works devoted to the history of Chinese drama, including four textbooks. 